\title{
Dynamics of carbon allocation in a deep-water population of the deciduous kelp Pleurophycus gardneri (Laminariales)
}

\author{
Clare Margaret Dominik ${ }^{1, *}$, Richard C. Zimmerman ${ }^{1,2}$ \\ ${ }^{1}$ The California State University, Moss Landing Marine Laboratories, 8272 Moss Landing Road, Moss Landing, \\ California 95039, USA
}

${ }^{2}$ Present address: Department of Ocean, Earth and Atmospheric Sciences, 4600 Elkhorn Avenue, Old Dominion University, Norfolk, Virginia 23529, USA

\begin{abstract}
Pleurophycus gardneri (Laminariales) is common in the low intertidal of the Northeast Pacific, but dominates many deep (30 to $40 \mathrm{~m}$ ) rocky reefs in central California. Seasonal dynamics of productivity and resource allocation of a deep-water population of this deciduous, stipitate kelp were studied to understand how blade abscission affects the annual carbon budget. Patterns of growth, metabolism, and carbon storage and mobilization were measured monthly for $1 \mathrm{yr}$ relative to in situ light and temperature, and used to model the annual carbon budget. The resulting carbon budget was used to determine if blade abscission effectively reduced respiratory demand during the winter period of low light availability. Metabolic properties (photosynthesis, photoacclimation, and respiration) were seasonally constant and showed evidence of photoacclimation to this deep, low-light environment. Blades grew between February and July, followed by senescence and sloughing from August to December. Concentrations of laminaran and mannitol increased in the blades from the onset of sloughing in August until just prior to blade abscission in mid-December, suggesting translocation of these carbohydrates may have occurred from the blade to the stipe and holdfast. Carbon budget estimates revealed that scalar irradiance measures overestimated the light available for photosynthesis of these paddle-shaped kelp blades by 50 to $75 \%$. The calculations also revealed that blade retention allowed for the maintenance of positive carbon balance throughout the year. Thus, conservation of the internal carbon reserve for metabolic survival during the low-light period does not appear to be a viable explanation for the deciduous life history of $P$. gardneri. Abscission may reduce hydrodynamic drag, thus minimizing the probability of dislodgment of entire plants during winter storm events, or promote spore dispersal as abscised blades and sori drift away from the parent holdfast.
\end{abstract}

KEY WORDS: Carbon budget $\cdot$ Photosynthesis $\cdot$ Abscission $\cdot$ Light acclimation Resale or republication not permitted without written consent of the publisher

\section{INTRODUCTION}

Autumnal leaf abscission has commonly been associated with conservation of energy in deciduous trees that synchronously shed their leaves in response to shortened winter photoperiods (Addicott 1982). Among deciduous trees, cold temperatures and/or light (day-length) are the most influential cues for abscission (Addicott 1982). Although light is also a common limiting factor for many marine ecosystems, including those dominated by the temperate to high latitude kelps (Dean 1985, Schiel \& Foster 1986), very few algae exhibit a deciduous life history. Canopy cover of Macrocystis pyrifera can limit light availability to understory algae in temperate latitudes (Reed \& Foster 1984, Watanabe et al. 1992), and episodic disturbance by large storms can influence the growth and persistence of algae that would otherwise be 
excluded by light limitation (Edwards 1998). However, there is no clear evidence that the newly settled algae undergo a seasonally adjusted metabolic response to light availability. In northern latitudes where light limitation is seasonally predictable, perennial kelps have evolved a variety of physiological mechanisms that allow them to survive through summer periods of nutrient limitation and winter periods of light limitation (Gagne et al. 1982). Laminaria solidungula, for example, uses stored carbohydrates accumulated during summer to complete $90 \%$ of its annual linear blade growth during the virtual darkness of the Arctic winter (Mann 1973, Chapman \& Craigie 1977, 1978, Dunton \& Schell 1986). Another mechanism may involve cellular photoacclimation to increased photosynthetic efficiency in low-light environments, through adjustments in total pigment content and/or the differential production of accessory pigments (Ramus 1983).

Another potential mechanism for surviving the lowlight conditions of winter is to reduce the total biomass and, thus, respiratory demand of the plant. Abscission of reproductive tissues is common among brown algae, including Nereocystis sp., Fucus spp., and Ascophyllum sp., and also possibly among Alaria sp., Lessoniopsis sp., and Pterogophora sp. (Addicott 1982). It is unclear whether blades of Laminaria sinclarii undergo true abscission or whether the blades are removed by physical abrasion (Markham 1972). Pleurophycus gardneri (Laminariales) is a deciduous perennial (Germann 1986) or pseudoperennial (Sears \& Wilce 1975) kelp, and the only one known to undergo programmed defoliation characterized by the synchronous abscission of the photosynthetic blade each winter. Germann (1989) suggested that abscission of the blade may be more advantageous than its retention, because the high photosynthetic efficiency and low respiration of the stipe and the holdfast may compensate for loss of the greater photosynthetic surface area of the blade, which has large respiratory requirements.

The distribution of Pleurophycus gardneri is commonly reported to be from Montague Island, Alaska, to Fort Bragg, California, USA, in the low intertidal to upper subtidal (Abbott \& Hollenberg 1976). Individuals are common in the northern part of the range, but are thought to be comparatively rare in the south. VanBlaricom et al. (1986), however, found low densities of $P$. gardneri $\left(<1\right.$ individual $\left.\mathrm{m}^{-2}\right)$ at depths above $15 \mathrm{~m}$, and much higher densities (up to 10 plants $\mathrm{m}^{-2}$ ) in deep water off the coast of Big Sur, California, USA. Stands with densities of 5 plants $\mathrm{m}^{-2}$ were recently observed at depths between 27 and $34 \mathrm{~m}$ in Carmel Bay, California, USA (Spalding et al. 2003). Their observations prompted our investigation into the ability of this kelp, previously thought restricted to intertidal regions, to flourish at $30 \mathrm{~m}$ depth almost $500 \mathrm{~km}$ south of its originally reported southern limit.

Many species of Laminariales have been rigorously studied to examine the relationships between light availability (Lüning 1979, Dunton 1985, Dunton \& Schell 1986, Dunton \& Jodwalis 1988), translocation and production of carbohydrates (Lüning et al. 1973, Chapman \& Craigie 1978), nitrate concentrations, and growth (Chapman et al. 1978, Germann et al. 1987). The objective of the present study was to explore the dynamics of carbon assimilation and its utilization for growth by Pleurophycus gardneri in this deep-water habitat. Physiological rate measurements, in situ growth studies, and chemical analysis were used to construct a numerical carbon budget that: (1) explored whether abscission was an effective mechanism for reducing whole plant respiratory demand and (2) determined the length of time that perennial tissues could survive on storage carbohydrates alone during the winter.

\section{MATERIALS AND METHODS}

Study site. The East Pinnacles reef system $\left(36^{\circ} 33^{\prime} 35^{\prime \prime} \mathrm{N}, 121^{\circ} 57^{\prime} 53^{\prime \prime} \mathrm{W}\right)$, located approximately $1.5 \mathrm{~km}$ offshore of Stillwater Cove, Carmel Bay, California, USA is characterized by high-relief granite pinnacles interspersed with large granitic boulders and small sand channels. Pinnacle tops above $20 \mathrm{~m}$ depth support a canopy of Macrocystis pyrifera, which is thinned annually by winter storms. The stipitate kelps Pterygophora californica, Eisenia arborea, and Pleurophycus gardneri were interspersed with giant kelp at $20 \mathrm{~m}$, but higher densities of $P$. gardneri were found in deeper water outside the giant kelp canopy. Fleshy red and geniculate coralline algae comprised a variably abundant algal turf beneath the stipitate kelps. Stipitate kelps outside the giant kelp canopy periodically lie flat and overlap one another when there is no surge or current (typically during summer months), providing the structure of a subsurface canopy. Nongeniculate coralline algae, along with red and occasionally green encrusting algae, generally occupied the primary substrate and were interspersed with encrusting invertebrates (see also Spalding et al. 2003).

Light availability. Photosynthetically active radiation (PAR, 400 to $700 \mathrm{~nm}$ ) was measured using a factory-calibrated LiCor LI193SA scalar (spherical) irradiance sensor (LiCor) and a data logger moored at $30 \mathrm{~m}$ depth at East Pinnacles throughout the study (June 2000 to May 2001). The sensor was mounted on top of a cement block (40 $\mathrm{cm}$ off the bottom), and placed on a flat rock (about $8 \times 2 \mathrm{~m}$ ) outside the kelp 
canopy. The rock was cleared in October 1999 and maintained free of all macroalgae within $1 \mathrm{~m}$ of the sensor throughout the study, to avoid shading the light sensor. In situ irradiance was averaged over 1 min and recorded at 15 min intervals during daylight hours. The irradiance sensor was cleaned of epiphytes, and the data logger was retrieved every month. The sensor was removed for thorough cleaning, and checked against another factory-calibrated scalar irradiance sensor (QSL 100, Biospherical Instruments) in the laboratory every 2 to 3 mo. Temperature was also recorded every $15 \mathrm{~min}$ using a factory-calibrated temperature logger (Stowaway logger; Onset Computer) that was checked against an alcohol thermometer in a constant temperature water bath $\left( \pm 0.5^{\circ} \mathrm{C}\right)$ each month. Brief interruptions of irradiance (June 2000) and temperature (July 2000) measurements resulted from equipment malfunction.

Growth phenology. A total of 9 to 10 adult (stipe length $>40 \mathrm{~cm}$ ) sporophytes were selected and tagged within a $20 \mathrm{~m}$ radius of the light meter each month, for growth measurements and subsequent analyses. Only intact individuals, mostly free of grazing marks and epiphytes, were selected, to reduce the variability in biomass measurements resulting from processes other than photosynthetic carbon assimilation and utilization. Grazing was rare during the growing season, but common after sloughing began in late July. Plants with minor peripheral grazing marks were used (grazing was not quantified) during the late summer and fall because of a lack of available non-grazed plants. Blade growth during spring (February to May 2001) occurred without sloughing, as indicated by the persistence of the abscission scar from the previous year. To calculate growth during months without sloughing, the average total blade area $\left(\mathrm{cm}^{2}\right.$ collection interval $\left.{ }^{-1}\right)$ each month was subtracted from the total blade area of the previous month (e.g. growth rate for March = average blade area March - average blade area for February), and divided by the time interval ( $1 \mathrm{mo}$, in this case). From June 2000 to November 2000, when sloughing was evident (Fig. 1), growth rates $\left(\mathrm{cm}^{2}\right.$ collection interval $\left.{ }^{-1}\right)$ of blades lacking an abscission scar were measured using the hole punch method to quantify new growth and the loss from sloughing (Parke 1948). A $5 \mathrm{~mm}$ diameter hole was punched through the midrib of each plant $10 \mathrm{~cm}$ above the base of the blade using a cork borer. Plants were collected approximately 4 wk after marking, placed in black plastic bags, brought to the surface, and stored in coolers during transport to the laboratory to prevent light or temperature shock. Collected plants were maintained in aquaria with running seawater at in situ temperatures for $\leq 24 \mathrm{~h}$ before initiating physiological measurements. Continuous shading (about 50 to $75 \%$ reduction of ambient, similar to in situ values) was provided to prevent photodamage. All measurements were completed within $5 \mathrm{~d}$ of collection. The wing $(\mathrm{W})$, midrib $(\mathrm{M})$, stipe $(\mathrm{S})$, and holdfast $(\mathrm{H})$ of each collected plant was weighed (fresh weight, FW). Subsamples of each tissue type were dried for $3 \mathrm{~d}$ at $60^{\circ} \mathrm{C}$ and used to develop FW to dry weight (DW) conversion factors. Sorus persistence and condition were noted qualitatively.

Absolute growth rate was calculated according to:

Growth $\left(\mathrm{cm}^{2}\right.$ collection interval $\left.{ }^{-1}\right)=\left(D_{2}-D_{1}\right) \times\left(W_{2}\right)$

where $D_{1}$ was the initial distance from the hole punch to the base of the blade and $W_{1}$ was the initial blade width; $D_{2}$ and $W_{2}$ were similar measurements performed at the end of the collection period. Sloughing was calculated similarly according to:

Sloughing $\left(\mathrm{cm}^{2}\right.$ collection interval $\left.{ }^{-1}\right)=\left(L_{1}-L_{2}\right) \times\left(W_{2}\right)$

where $L_{1}$ was the length of the blade from the distal end to the initial hole punch mark at Time 1 , and $L_{2}$ was the length of the blade from the distal end to the hole punch at Time 2. Although the actual shape of the blade resembles a truncated ellipse, frills on the edges of the wing add area to the blade, but are difficult to measure precisely. Consequently, blade area was calculated assuming a rectangular shape to incorporate the wing frills.

DW was calculated from conversion factors derived from tissue samples weighed before and after drying (Table 1). Conversion factors for DW/carbon content 
were determined from dry ground samples of each tissue type. Carbon analysis was performed by Analytical Laboratory Services, Marine Science Institute, UC Santa Barbara, California, USA, using the Dumas combustion method (automated organic elemental analyzer CEC 440HA, Exeter Analytical, standardized against acetanilide $\pm 0.3 \%$ precision).

Photosynthesis and respiration. Monthly measurements of photosynthesis and dark respiration were made using tissue samples excised from the collected plants ( $\mathrm{n}=9$ or 10$)$. Photosynthetic rates were determined polarographically using $2 \mathrm{~cm}^{2}$ sections of wing and midrib tissues cut between 10 and $40 \mathrm{~cm}$ above the base of the blade. Samples of stipe tissue

Table 1. Pleurophycus gardneri. Conversion table for normalizing among units (FW: fresh weight; DW: dry weight). Data are means $( \pm 1 \mathrm{SE}, \mathrm{n}=10$, except September and November, $\mathrm{n}=9$, and February wing, $\mathrm{n}=8$ )

\begin{tabular}{|c|c|c|c|c|}
\hline & Wing & Midrib & Stipe & Holdfast \\
\hline \multicolumn{5}{|c|}{ DW as \% FW } \\
\hline Jun & $12(0.5)$ & $10(0.3)$ & $21(0.6)$ & $19(0.6)$ \\
\hline Jul & $13(0.5)$ & $11(0.3)$ & $24(0.7)$ & $21(0.8)$ \\
\hline Aug & $14(0.4)$ & $11(0.6)$ & $25(0.6)$ & $24(0.5)$ \\
\hline Sep & $14(0.3)$ & $10(0.5)$ & $25(0.4)$ & $22(0.8)$ \\
\hline Oct & $14(0.4)$ & $10(0.6)$ & $26(0.3)$ & $24(0.8)$ \\
\hline Nov & $14(0.4)$ & $10(0.3)$ & $27(0.5)$ & $23(0.8)$ \\
\hline Dec & \multicolumn{2}{|c|}{ Abscised } & $28(0.4)$ & $24(0.7)$ \\
\hline Jan & \multicolumn{2}{|c|}{ Bladeless } & $26(0.5)$ & $23(0.6)$ \\
\hline Feb & $9(0.5)$ & $11(0.6)$ & $25(0.6)$ & $23(0.3)$ \\
\hline Mar & $9(0.2)$ & $8(0.3)$ & $23(0.4)$ & $21(0.5)$ \\
\hline Apr & $9(0.2)$ & $9(0.1)$ & $21(0.5)$ & $21(0.7)$ \\
\hline May & $6(0.2)$ & $5(0.1)$ & $13(0.2)$ & $13(0.3)$ \\
\hline \multicolumn{5}{|c|}{ g DW plant ${ }^{-1}$} \\
\hline Jun & $8.3(0.91)$ & $3.0(0.34)$ & $4.8(0.39)$ & $1.5(0.18)$ \\
\hline Jul & $10.3(0.88)$ & $4.0(0.42)$ & $7.0(0.88)$ & $1.8(0.12)$ \\
\hline Aug & $8.2(0.62)$ & $4.1(0.31)$ & $7.3(0.74)$ & $1.9(0.21)$ \\
\hline Sep & $6.0(0.94)$ & $3.4(0.62)$ & $6.8(0.99)$ & $2.0(0.26)$ \\
\hline Oct & $3.2(0.43)$ & $3.3(0.54)$ & $10.4(1.08)$ & $2.2(0.24)$ \\
\hline Nov & $1.7(0.19)$ & $2.0(0.27)$ & $8.5(0.74)$ & $2.0(0.22)$ \\
\hline Dec & \multicolumn{2}{|c|}{ Abscised } & $8.7(0.67)$ & $1.9(0.18)$ \\
\hline Jan & \multicolumn{2}{|c|}{ Bladeless } & $9.1(0.86)$ & $1.7(0.12)$ \\
\hline Feb & $0.2(.02)$ & $0.1(0.02)$ & $6.8(0.57)$ & $1.6(0.13)$ \\
\hline Mar & $1.0(0.11)$ & $0.4(0.04)$ & $6.2(0.57)$ & $1.8(0.14)$ \\
\hline Apr & $2.8(0.23)$ & $0.9(0.05)$ & $4.7(0.38)$ & $1.7(0.14)$ \\
\hline May & $2.5(0.18)$ & $1.0(0.07)$ & $4.5(0.53)$ & $1.0(0.12)$ \\
\hline \multicolumn{5}{|c|}{$\mathrm{g} \mathrm{C} \mathrm{g}^{-1} \mathrm{DW}$} \\
\hline Jun & $0.25(0.004)$ & $0.23(0.006)$ & $0.32(0.003)$ & $0.31(0.004)$ \\
\hline Jul & $0.25(0.005)$ & $0.23(0.007)$ & $0.32(0.004)$ & $0.30(0.004)$ \\
\hline Aug & $0.23(0.021)$ & $0.25(0.014)$ & $0.33(0.011)$ & $0.33(0.004)$ \\
\hline Sep & $0.21(0.049)$ & $0.21(0.010)$ & $0.33(0.003)$ & $0.33(0.006)$ \\
\hline Oct & $0.24(0.003)$ & $0.22(0.010)$ & $0.34(0.003)$ & $0.32(0.004)$ \\
\hline Nov & $0.23(0.015)$ & $0.22(0.011)$ & $0.35(0.004)$ & $0.33(0.004)$ \\
\hline Dec & \multicolumn{2}{|c|}{ Abscised } & $0.35(0.004)$ & $0.31(0.005)$ \\
\hline Jan & \multicolumn{2}{|c|}{ Bladeless } & $0.35(0.006)$ & $0.32(0.009)$ \\
\hline Feb & $0.22(0.026)$ & $0.26(0.001)$ & $0.35(0.002)$ & $0.32(0.009)$ \\
\hline Mar & $0.23(0.004)$ & $0.21(0.005)$ & $0.32(0.008)$ & $0.33(0.010)$ \\
\hline Apr & $0.20(0.019)$ & $0.21(0.003)$ & $0.29(0.030)$ & $0.32(0.007)$ \\
\hline May & $0.22(0.006)$ & $0.20(0.002)$ & $0.30(0.007)$ & $0.30(0.006)$ \\
\hline
\end{tabular}

were cut below the second growth constriction, and holdfast samples were taken from the youngest haptera (outer-most and least fouled). Photosynthesis and dark respiration were measured following Zimmerman et al. (1989) using an oxygen electrode in a water-jacketed incubation chamber (5 $\mathrm{ml} \mathrm{vol}$; Rank Bros.). The incubation chamber was maintained within $0.5^{\circ} \mathrm{C}$ of the average in situ temperature recorded during the month prior to collection, which ranged from $9^{\circ} \mathrm{C}$ in February 2001 to $12.5^{\circ} \mathrm{C}$ in October, with a circulating water bath. Respiration was measured in complete darkness. Photosynthesis was measured at 10 irradiances (1 plant irradiance level ${ }^{-1}$ ) using an incandescent light source (Fiber-Lite High Intensity Illuminator Series 180, Dolan-Jenner Instruments, $150 \mathrm{~W}$ bulb) to construct monthly photosynthesis versus irradiance ( $P$ versus $E$ ) curves. These tissue samples were oriented normal to the irradiance path inside the electrode chamber.

Carbohydrate and photosynthetic pigment composition. The soluble carbohydrates mannitol and laminaran were extracted from ground, dry tissue (W, M, S, and $\mathrm{H}$ ) using hot $\left(80^{\circ} \mathrm{C}\right)$ ethanol (Chapman \& Craigie 1977). Mannitol was analyzed by the periodatechromotropic acid method (Lambert \& Neish 1950), standardized using D-mannitol. Laminaran concentrations were determined using anthrone (Yemn \& Willis 1954), standardized with D-glucose. Mannitol and laminaran concentrations were converted to moles of carbon based on their molecular formulas (1 mol mannitol or laminaran $=6 \mathrm{~mol}$ carbon $=72 \mathrm{~g}$ carbon mol ${ }^{-1}$ sugar). Chlorophyll $(a+c)$ and fucoxanthin were extracted from fresh tissue samples using a 2-step DMSO (dimethylsulfoxide), methanol-acetone extraction procedure. Pigments were measured spectrophotometrically, and pigment concentrations were calculated following Seely et al. (1972).

Statistical analysis. Monthly gross $P$ versus $E$ curves were constructed for each tissue type using the exponential function of Webb et al. (1974). Parameter values and variance estimates for the maximum rate of light-saturated photosynthesis $\left(P_{\mathrm{MAX}}\right)$ and the light-limited initial slope $(\alpha)$ were estimated using an iterative, least-squares, non-linear curve-fitting routine based on the Marquardt-Levenberg algorithm in Sigma Plot (Jandel Scientific). Dark respiration $(R)$ was measured and subtracted from gross production in the carbon budget model at each 15 min interval continuously throughout the year. Metabolic 
measurements were converted from oxygen-based to carbon-based units using photosynthetic and respiratory quotients of 1.2 and $1.0 \mathrm{~mol} \mathrm{O}_{2} \mathrm{~mol}^{-1} \mathrm{CO}_{2}$, respectively. The analysis produced an aggregate estimate of $P_{\mathrm{MAX}}$ and $\alpha$ for each tissue each month because only a simple monthly $P$ versus $E$ curve was constructed from 10 independent samples measured at 10 different irradiances each month. The estimated variances associated with the monthly, aggregate estimate of $P_{\mathrm{MAX}}$ and $\alpha$ were calculated according to Zimmerman et al. (1987) and used to identify significant temporal variation in monthly values of $P_{\mathrm{MAX}}$ and $\alpha$ using multiple $t$-tests with probabilities adjusted using the Bonferroni procedure.

Respiration, growth, sloughing, and chemical composition measurements were analyzed for temporal differences using 1-way ANOVA ( $\mathrm{p} \leq 0.05)$ and LSD (least significant difference) planned multiple comparison tests (Sokal \& Rohlf 1969). For most months $\mathrm{n}=10$, except for September and November, when $\mathrm{n}=9$, and February, when $n=4$ to 6 , depending on the amount of tissue present for analysis. Some of the data required transformation to meet the equal variance assumption of ANOVA. Square-root transformations were applied to the growth, sloughing, stipe chlorophyll, and holdfast pigment data. Log-transformations were applied to the mannitol, laminaran, and stipe fucoxanthin data. Data for plant size, wing pigment content, and midrib chlorophyll content met all assumptions of ANOVA without transformation. Post-hoc differences were indicated on all graphs by different heights of horizontal lines running through the data on each relevant figure. Monthly means that were significantly different from some, but not all, other months have a vertically sloping line running across them.

Carbon budget. Carbon budgets were calculated using rates of light-dependent photosynthesis, dark respiration, and sloughing. Photosynthetic production was calculated for each tissue type $\left(P_{\text {gross }(\mathrm{W}, \mathrm{M}, \mathrm{S}, \mathrm{H})}\right)$ from in situ irradiance recorded at 15 min intervals according to the exponential function in Webb et al. (1974):

$$
P_{\text {gross }(\mathrm{W}, \mathrm{M}, \mathrm{S}, \mathrm{H})}=P_{\mathrm{MAX}(\mathrm{W}, \mathrm{M}, \mathrm{S}, \mathrm{H})}\left(1-\mathrm{e}^{\frac{-\alpha_{(\mathrm{W}, \mathrm{M}, \mathrm{S}, \mathrm{H})} E}{P_{\mathrm{MAX}(\mathrm{W}, \mathrm{M}, \mathrm{S}, \mathrm{H})}}}\right)
$$

Irradiance was assumed to be constant during each 15 min interval. During non-winter phases of growth (all plant parts present), the carbon budget was calculated as:

$P_{\mathrm{NET}(\mathrm{W}, \mathrm{M}, \mathrm{S}, \mathrm{H})}=P_{\mathrm{gross}(\mathrm{W}, \mathrm{M}, \mathrm{S}, \mathrm{H})}-$ Sloughing $_{(\mathrm{W}, \mathrm{M})}-R_{(\mathrm{W}, \mathrm{M}, \mathrm{S}, \mathrm{H})}$

where $R$ is dark respiration. The model was initiated using plant size estimated for May 2000, by subtracting growth and adding sloughing from plant size measured in June 2000. The predictive ability of the back-calculation was assessed by performing it for all
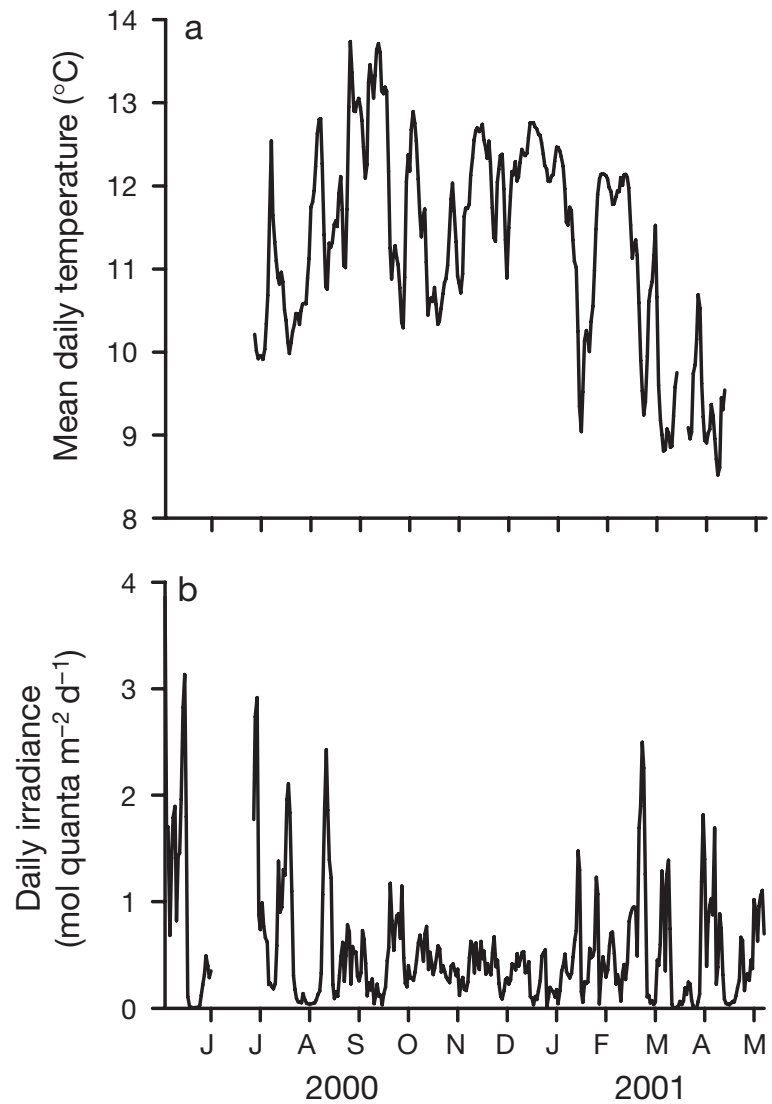

Fig. 2. Time series of (a) daily mean temperature and (b) total daily irradiance at the study site in Carmel Bay (depth $=30 \mathrm{~m}$ )

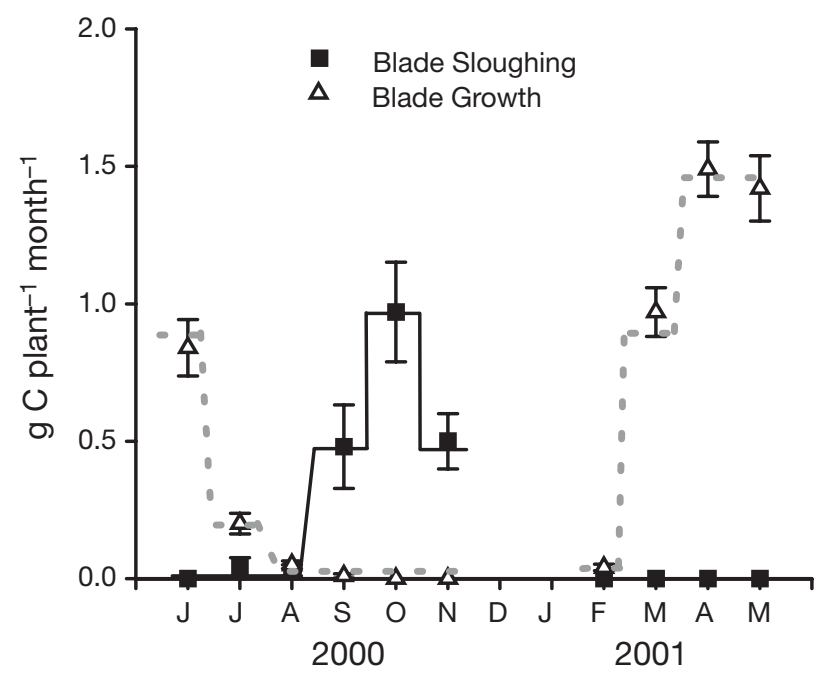

Fig. 3. Pleurophycus gardneri. Blade growth and sloughing (mean $\pm 1 \mathrm{SE}$ ). Horizontal lines running through the data at the same height indicate statistically identical values among monthly means determined by least significant difference post hoc analysis (dashed for growth and solid for sloughing) 
Table 2. Pleurophycus gardneri. ANOVA results for differences in parameters by tissue type among months. Significance represented by ${ }^{*}<0.05,{ }^{* *}<0.01,{ }^{* * *}<0.001$, ns: not significant

\begin{tabular}{|c|c|c|c|c|c|}
\hline Treatment & $\mathrm{df}$ & MS & $F$ & $\mathrm{p}$ & Signif. \\
\hline \multicolumn{6}{|l|}{ Respiration } \\
\hline Wing & 9 & 0.00706 & 1.94 & 0.0619 & ns \\
\hline Error & 62 & 0.00363 & & & \\
\hline Midrib & 9 & 0.00019 & 1.05 & 0.4112 & ns \\
\hline Error & 60 & 0.00018 & & & \\
\hline Stipe & 11 & 0.00010 & 3.29 & $<0.001$ & *** \\
\hline Error & 98 & 0.00003 & & & \\
\hline Holdfast & 11 & 0.00033 & 0.94 & 0.5100 & ns \\
\hline Error & 81 & 0.00036 & & & \\
\hline \multicolumn{6}{|c|}{ Carbon content } \\
\hline Wing & 9 & 7.0130 & 32.248 & $<0.001$ & $* * *$ \\
\hline Error & 82 & 0.2170 & & & \\
\hline Midrib & 9 & 1.0990 & 24.097 & $<0.001$ & $* * *$ \\
\hline Error & 82 & 0.0460 & & & \\
\hline Stipe & 11 & 5.1100 & 8.65 & $<0.001$ & $* * *$ \\
\hline Error & 106 & 0.5910 & & & \\
\hline Holdfast & 11 & 0.1200 & 4.294 & $<0.001$ & $* * *$ \\
\hline Error & 106 & 0.0280 & & & \\
\hline \multicolumn{6}{|l|}{ Growth } \\
\hline Blade & 9 & 3.32800 & 233.527 & $<0.001$ & $* * *$ \\
\hline Error & 89 & 0.01400 & & & \\
\hline \multicolumn{6}{|l|}{ Sloughing } \\
\hline Blade & 5 & 1.231 & 23.597 & $<0.001$ & $* * *$ \\
\hline Error & 53 & 0.052 & & & \\
\hline \multicolumn{6}{|l|}{ Chl } \\
\hline Wing & 9 & 0.17200 & 20.93 & $<0.001$ & $* * *$ \\
\hline Error & 84 & 0.00800 & & & \\
\hline Midrib & 9 & 0.01200 & 7.10 & $<0.001$ & $* * *$ \\
\hline Error & 84 & 0.00200 & & & \\
\hline Stipe & 11 & 0.01800 & 8.24 & $<0.001$ & $* * *$ \\
\hline Error & 106 & 0.00200 & & & \\
\hline Holdfast & 11 & 0.00800 & 2.44 & 0.0089 & $* *$ \\
\hline Error & 106 & 0.00300 & & & \\
\hline \multicolumn{6}{|c|}{ Fucoxanthin } \\
\hline Wing & 9 & 0.02500 & 10.46 & $<0.001$ & $* * *$ \\
\hline Error & 84 & 0.00200 & & & \\
\hline Midrib & 9 & 0.00600 & 7.22 & $<0.001$ & $* * *$ \\
\hline Error & 84 & 0.00100 & & & \\
\hline Stipe & 11 & 0.17600 & 2.49 & 0.0091 & $* *$ \\
\hline Error & 106 & 0.07100 & & & \\
\hline Holdfast & 11 & 0.00500 & 3.52 & $<0.001$ & $* * *$ \\
\hline Error & 106 & 0.00100 & & & \\
\hline \multicolumn{6}{|l|}{ Mannitol } \\
\hline Total plant & 11 & 6.414 & 18.988 & $<0.001$ & $* * *$ \\
\hline Error & 106 & 0.338 & & & \\
\hline \multicolumn{6}{|l|}{ Laminaran } \\
\hline Total plant & 11 & 4.038 & 15.844 & $<0.001$ & $* * *$ \\
\hline Error & 106 & 0.255 & & & \\
\hline
\end{tabular}

subsequent months, and regressing calculated plant size against measured plant size. Net photosynthetic production $\left(P_{\mathrm{NET}}\right)$ was added to the initial value (minus losses from sloughing and respiration) to predict change in plant size at each 15 min interval:

$$
\text { NewPlantSize }=\text { OldPlantSize }+\left(P_{\mathrm{NET}} \times \text { Time }\right)
$$

Plant size increased when $P_{\mathrm{NET}}$ was positive (i.e. when production exceeded losses). All parameters were converted to grams of carbon per plant per 15 min using the conversion factors provided in Table 1. Plant size decreased when $P_{\mathrm{NET}}$ was negative. To estimate plant size, carbon budgets were integrated over the collection interval ranging from 3 to $5 \mathrm{wk}$. The carbon budget calculations were validated by linear regression of predicted plant size against measured plant size. Average daily $P_{\mathrm{NET}}$ was also modeled assuming no blade sloughing or abscission to test the potential impact of blade retention (no abscission) during winter on the whole-plant carbon balance. Within a given month, average daily $P_{\mathrm{NET}}$ with abscission versus average daily $P_{\mathrm{NET}}$ with no abscission was analyzed for significant differences using a 1-sample $t$-test.

\section{RESULTS}

Daily average temperatures at East Pinnacles (30 m depth) were highest from August to February, ranging from almost 9.5 to $14^{\circ} \mathrm{C}$. Temperatures were lowest from March to July, ranging from 8.5 to $12.5^{\circ} \mathrm{C}$. Irradiances at $30 \mathrm{~m}$ were highly variable, ranging from almost 0 to almost 4 mol quanta $\mathrm{m}^{-2} \mathrm{~d}^{-1}$ in the summer when phytoplankton blooms and/or persistent coastal stratus are common to this region of central California. Average winter irradiances ranged from almost 0 to about 1 mol quanta $\mathrm{m}^{-2} \mathrm{~d}^{-1}$ (Fig. 2).

\section{Growth phenology}

Pleurophycus gardneri blades grew for approximately 5 mo from February to July (Fig. 3). Growth was highest in spring and slowed dramatically between June and July. Sloughing began in August and September, as indicated by the loss of the abscission scar from the distal end of the blade (Fig. 1). Sloughing continued without growth until only the proximal one third of the blade remained in November. Most P. gardneri produced a single variably sized (20 to $75 \mathrm{~cm}^{2}$ ) sorus patch on the midrib of each blade between April and June. Sori persisted until September, when the patches were sloughed along with vegetative blade tissue. Secondary sori developed proximal 
Table 3. Pleurophycus gardneri. Annual mean values of light-saturated gross photosynthesis $\left(P_{\mathrm{MAX}}\right)$, the initial slope $(\alpha)$, and dark respiration $(R)$ for each tissue type. Probabilities for post-hoc tests: ${ }^{*}<0.05,{ }^{* *}<0.001$, ns: not significant

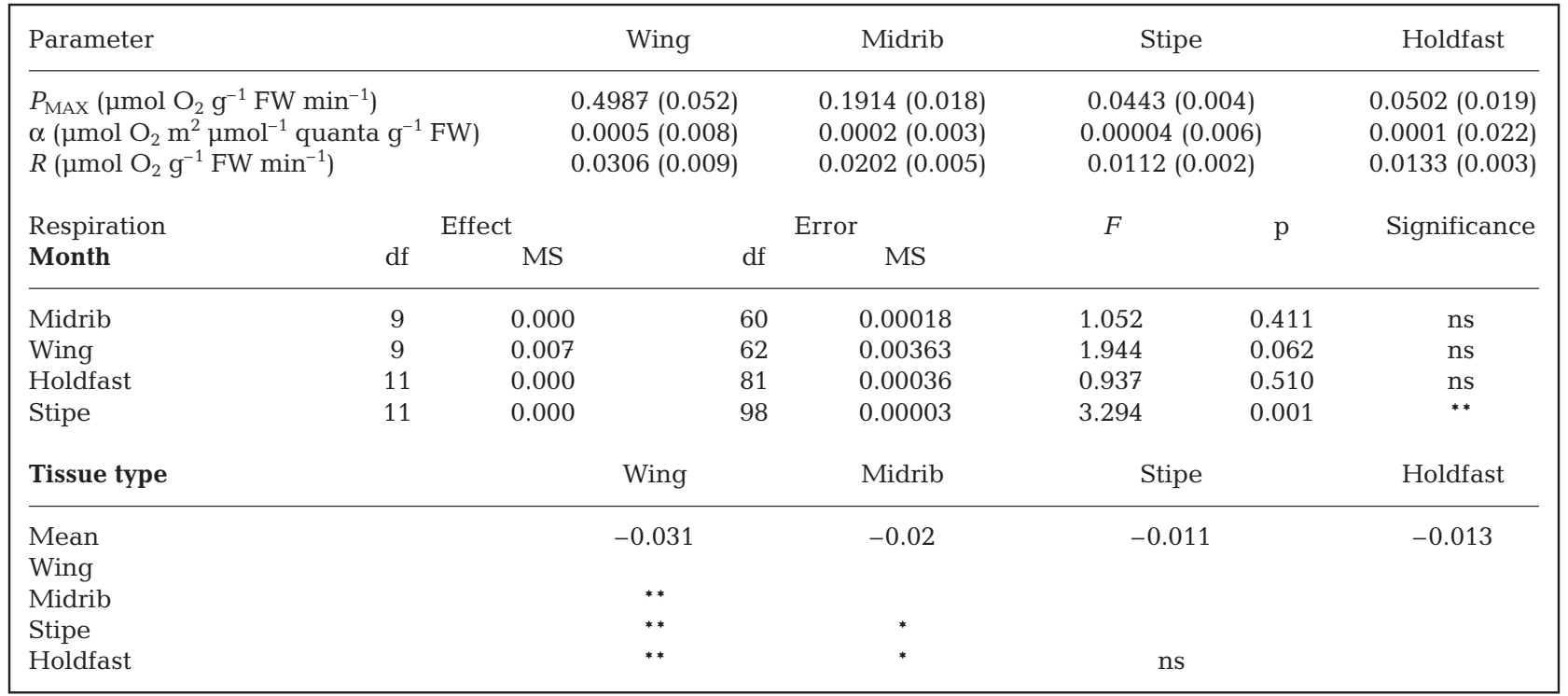

Table 4. Pleurophycus gardneri. Comparative average values for tissue composition, photosynthesis, and respiration of deepwater versus intertidal populations, and comparisons with other kelps. Data are for blade tissues unless otherwise noted

\begin{tabular}{|c|c|c|c|}
\hline Parameter & $\begin{array}{l}\text { Deep } \\
\text { P. gardneri }\end{array}$ & $\begin{array}{c}\text { Intertidal } \\
\text { P. gardneri } \\
\text { (Germann 1986) }\end{array}$ & $\begin{array}{c}\text { Macrocystis pyrifera, } \\
\text { Pterogophora californica } \\
\text { (Zimmerman \& Kremer 1986, } \\
\text { R. C. Zimmerman unpubl. data) }\end{array}$ \\
\hline Carbon (\% DW) & $20-25$ & $26-30$ & $33^{\mathrm{a}}$ \\
\hline Mannitol (\% FW) & 0.5 & 1.44 & $0.5^{\mathrm{a}}$ \\
\hline Laminaran (\% FW) & 0.2 & 0.024 & $0.2^{\mathrm{a}}$ \\
\hline $\begin{array}{r}\text { Chl a/Chl c (blade) } \\
\text { (stipe) }\end{array}$ & $\begin{array}{c}5 \\
0.35\end{array}$ & $\begin{array}{c}3 \\
0,3\end{array}$ & $1.7,3.5$ \\
\hline $\begin{array}{r}\text { Chl a/Fucoxanthin (blade) } \\
\text { (stipe) }\end{array}$ & $\begin{array}{c}1.8 \\
1\end{array}$ & $\begin{array}{l}1.7 \\
0,6\end{array}$ & $0.56,0.5$ \\
\hline 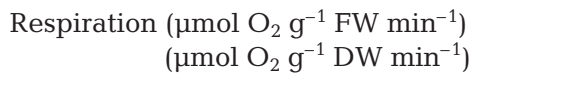 & $\begin{array}{l}0.03 \\
0.25\end{array}$ & $\begin{array}{c}0.05 \\
0.416\end{array}$ & $0.05,0.02$ \\
\hline $\begin{array}{r}P_{\mathrm{MAX}}\left(\mu \mathrm{mol} \mathrm{O} \mathrm{O}_{2} \mathrm{~g}^{-1} \mathrm{FW} \mathrm{min}^{-1}\right) \\
\left(\mu \mathrm{mol} \mathrm{O} \mathrm{g}^{-1} \mathrm{DW} \mathrm{min}^{-1}\right)\end{array}$ & $\begin{array}{c}0.5 \\
4.12\end{array}$ & $\begin{array}{c}0.5 \\
4.12\end{array}$ & $0.6,0.42$ \\
\hline $\begin{array}{l}\alpha \text { (photosynthetic efficiency) } \\
\quad\left(\mu \mathrm{mol} \mathrm{O} \mathrm{m}^{2} \mu \mathrm{mol}^{-1} \text { quanta } \mathrm{g}^{-1} \mathrm{FW}\right) \\
\quad\left(\mu \mathrm{mol} \mathrm{O} \mathrm{O}_{2} \mathrm{mmol}^{-1} \text { quanta } \mathrm{g}^{-1} \mathrm{DW}\right)\end{array}$ & $\begin{array}{l}0.0005 \\
0.0042\end{array}$ & $\begin{array}{l}0.00015 \\
0.002\end{array}$ & $0.009,0.007$ \\
\hline $\begin{array}{c}P_{\mathrm{MAX}} / R \text { (blade) } \\
\text { (stipe) }\end{array}$ & $\begin{array}{c}16 \\
5\end{array}$ & $\begin{array}{c}10 \\
2\end{array}$ & 12,20 \\
\hline$P_{\mathrm{MAX}} \operatorname{chl~} a^{-1}\left(\mu \mathrm{mol} \mathrm{O} \mathrm{mg}^{-1} \mathrm{chl} a \min ^{-1}\right)$ & 1.1 & 1.9 & $3.7,4.5$ \\
\hline$E_{\mathrm{k}}=P_{\mathrm{MAX}} / \alpha\left(\mu \mathrm{mol}^{-1}\right.$ quanta $\left.\mathrm{m}^{-2} \mathrm{~s}^{-1}\right)$ & 17 & 56 & 67,64 \\
\hline Fucoxanthin (mg g $\left.{ }^{-1} \mathrm{FW}\right)$ & 0.25 & 0.1 & $0.5,0.8$ \\
\hline $\mathrm{Chl} \mathrm{a}\left(\mathrm{mg} \mathrm{g}^{-1} \mathrm{FW}\right)$ & 0.45 & 0.27 & $0.22,0.40$ \\
\hline
\end{tabular}




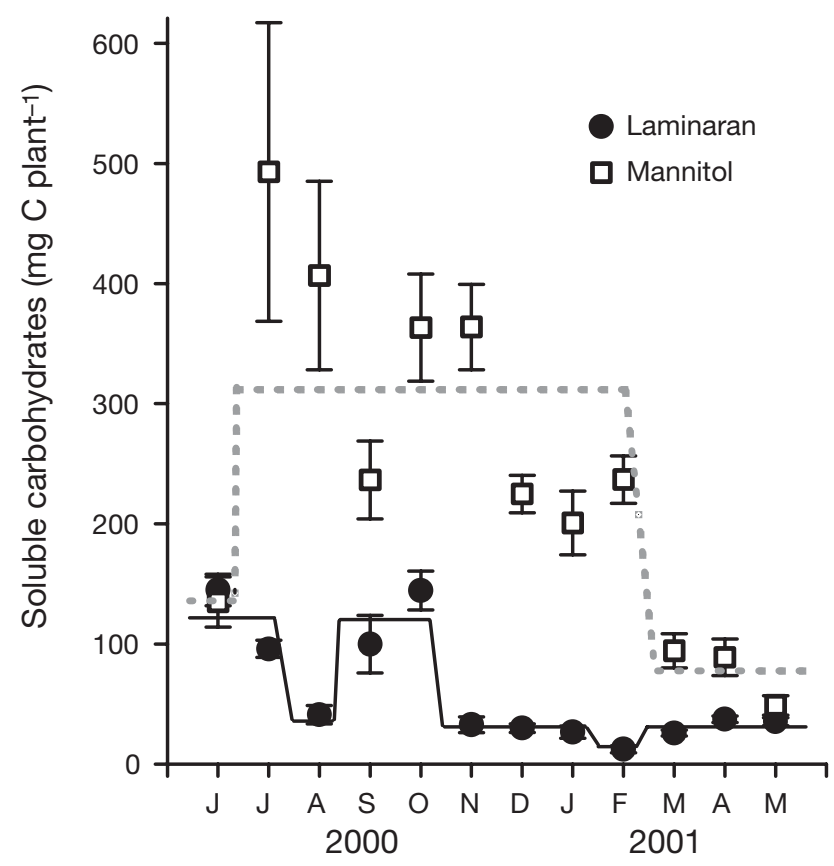

Fig. 4. Pleurophycus gardneri. Mannitol- and laminaransoluble carbohydrate concentrations of entire plants (mean \pm $1 \mathrm{SE}$ ). Horizontal lines running through the data at the same height indicate statistically identical values among monthly means determined by least significant difference post-hoc analysis (dashed for mannitol and solid for laminaran)

to the spring patches on about half of the plants (authors' pers. obs.) prior to abscission in midNovember. Prior to abscission, the upper portion of the stipe (between the meristem and where the stipe narrowed) began to darken. Abscission was completed by mid-December, and the bladeless period lasted until the beginning of February (Figs. 1 \& 3).

\section{Photosynthesis and respiration}

The photosynthetic parameters $P_{\text {MAX }}$ and $\alpha$ were temporally constant throughout the study in all tissues, as no significant difference was detected by multiple $t$-tests using the Bonferroni correction. Respiration $(R)$ was also constant over time in all tissues, except the stipe, where it was slightly, but significantly, lower during winter (Table 2). Metabolic rates ( $P_{\text {MAX }}$ and $R$ ) and photosynthetic efficiency $(\alpha)$ were highest in wing tissue, followed by midrib, and then stipe and holdfast (Table 3 ). The average $P_{\text {MAX }} / R$ value for the wing tissue of the deep plants was 15; it was 9 for intertidal plants studied by Germann (1986); both fall in the range of other kelps (Table 4). Generalized $P$ versus $E$ curves for wing tissue of the deep-water population examined here revealed a biomass-specific value of $P_{\text {MAX }}$ that was similar to the value reported by Germann (1986) for
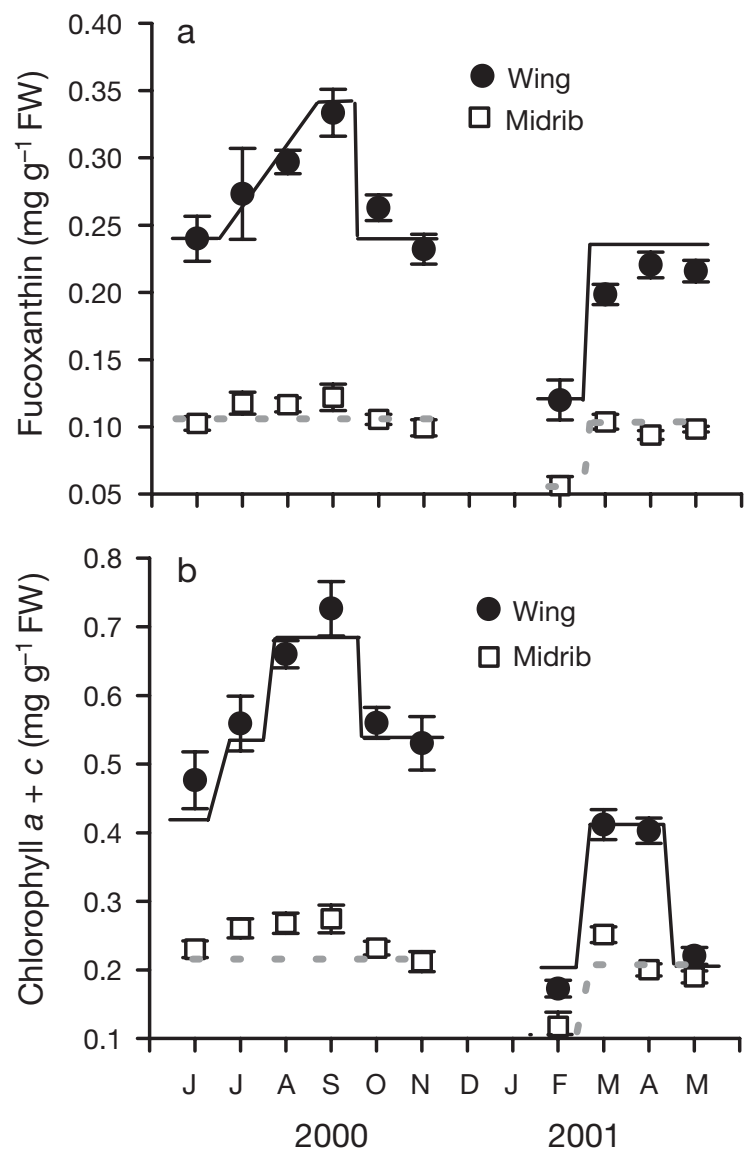

Fig. 5. Pleurophycus gardneri. (a) Fucoxanthin and (b) chlorophyll $(a+c)$ concentrations for midrib and wing (mean $\pm 1 \mathrm{SE}$ ). Horizontal lines running through the data at the same height indicate statistically identical values among monthly means determined by least significant difference post-hoc analysis (dashed for midrib and solid for wing)

intertidal plants (Table 4). Biomass-specific photosynthetic efficiency $(\alpha)$ was 2 to 3 times greater in the deep plants regardless of how the data were normalized (FW, DW) (Table 4). When normalized to chlorophyll, $\alpha$ was similar in the deep and intertidal populations. Chlorophyll-normalized $P_{\mathrm{MAX}}$, in contrast, was lower in the deep-water population. This pattern appears to represent a classic photoacclimation response common among shade-adapted algae.

\section{Chemical composition}

Carbohydrate concentrations (mg C plant ${ }^{-1}$ ) decreased while plants were growing, increased during sloughing, and continually decreased after abscission through blade initiation and growth in spring (Fig. 4). Mannitol represented up to $8 \%$ of the total DW and averaged $5 \%$ DW. Laminaran accounted for only 1 to $2 \%$ of DW. Summer and fall concentrations of lami- 
naran and mannitol were significantly greater than those in winter and spring (Table 2).

Wing tissues always had the highest pigment concentrations, followed by the midrib, stipe, and holdfast. Concentrations of fucoxanthin and chlorophyll $(a+c)$ in wing and midrib tissues increased throughout the spring, peaked in late summer, and decreased significantly by late fall (Fig. 5, Table 2). Chlorophyll $(a+c)$ concentrations in the stipe began increasing in winter and were greatest in spring, while concentrations in the holdfast were greatest in winter and dropped in the spring (Fig. 6, Table 2). Fucoxanthin concentrations in the stipe and holdfast were significantly greater in some late summer and spring months than in some fall and winter months (Fig. 6, Table 2). However, post hoc results were ambiguous, and only the holdfast fucoxanthin concentrations in October were clearly different from all the others (Fig. 6). The average ratio of chl $a / \mathrm{chl} C$ for the wing tissue was 5 , and the chl a/fucoxanthin ratio was 1.8 (Table 4 ). The mass of the wing and midrib was significantly lower in spring (during blade initiation) than in the previous summer (Fig. 7a, Table 2). Carbon content of the stipe in-
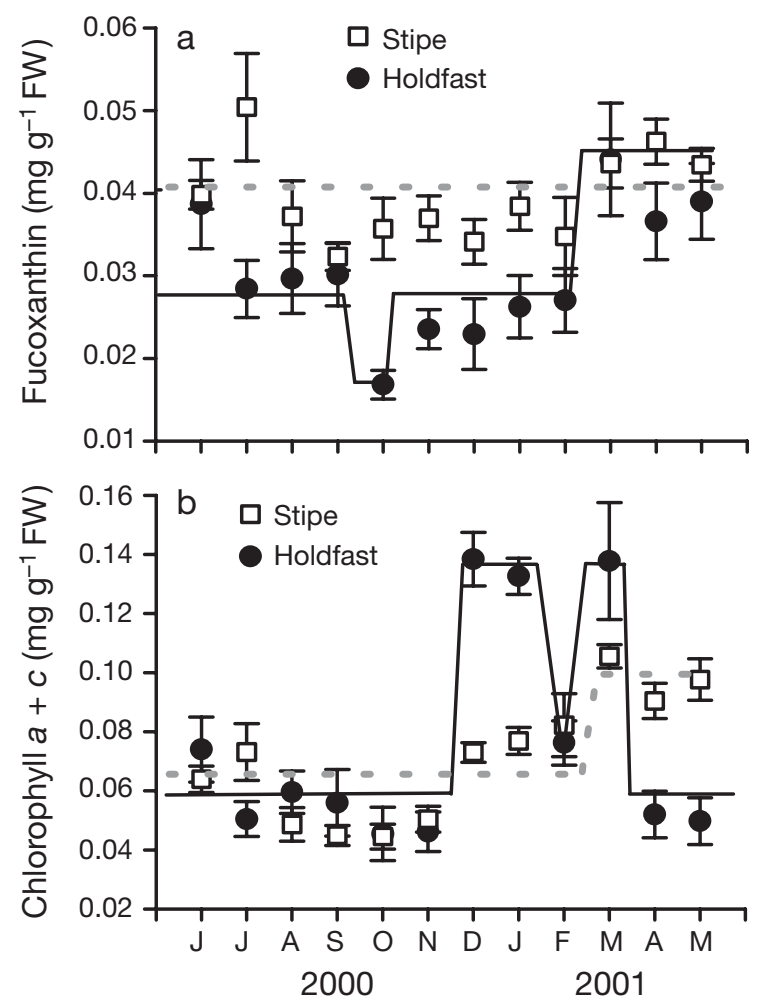

Fig. 6. Pleurophycus gardneri. (a) Fucoxanthin and (b) chlorophyll $(a+c)$ concentrations for stipe and holdfast (mean $\pm 1 \mathrm{SE}$ ). Horizontal lines running through the data at the same height indicate statistically identical values among monthly means determined by least significant difference post-hoc analysis (dashed for stipe and solid for holdfast) creased during sloughing as day-length decreased and growth ceased, while carbon content of the holdfast remained relatively constant (Fig. 7b).

\section{Carbon budget}

The carbon budget calculations required an initial value for plant size. Although field studies began in May 2000, plant size was not measured until June 2000. In order to begin the carbon budget calculations with the initiation of the light data, it was necessary to back-calculate plant size for May from the initial morphometric data collected in June by inverting Eq. (5) to solve for old plant size. When this calculation was performed for each month, it was found that measured plant size was a strong predictor of plant size the previous month (Previous Size $=0.92 \times$ New Size +0.26 , $\mathrm{r}^{2}=0.87$, regression ANOVA $=61.75, \mathrm{df}=1,11, \mathrm{p}<$ 0.0001). This relationship was used to estimate initial plant size in May 2000 for seeding the model.

When using the scalar irradiances measured in situ, the model overestimated plant size, and therefore
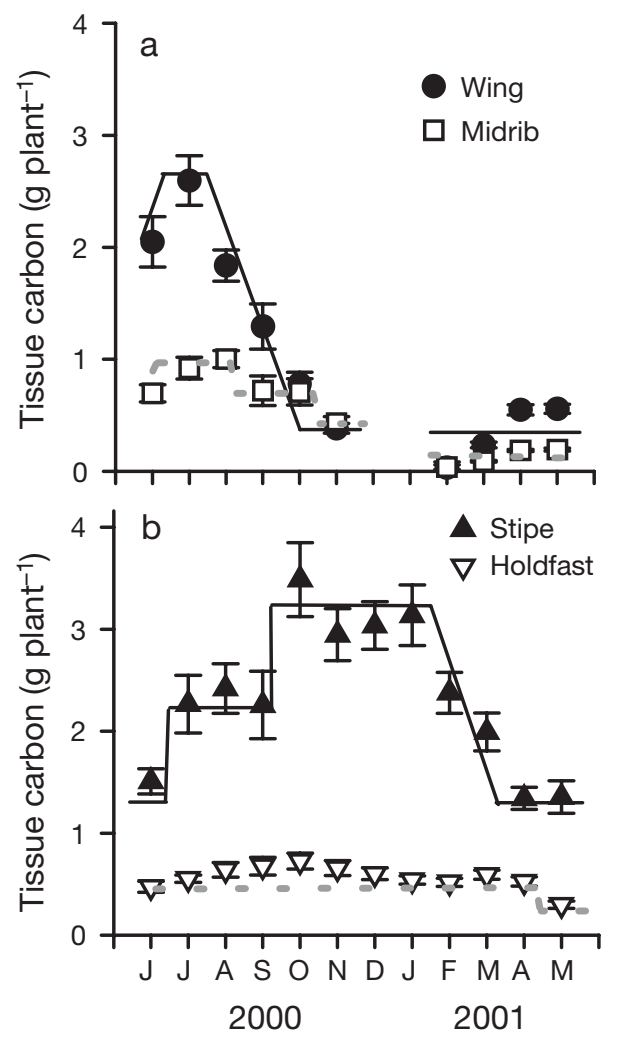

Fig. 7. Pleurophycus gardneri. Total carbon content of (a) wing and midrib and (b) stipe and holdfast (mean $\pm 1 \mathrm{SE}$ ). Horizontal lines running through the data at the same height indicate statistically identical values among monthly means determined by least significant difference post-hoc analysis (solid for wing and stipe and dashed for midrib and holdfast) 
growth during summer, spring, and fall, and underestimated plant size during winter. Consequently, the seasonal pattern in modeled plant size was exaggerated relative to measured plant size (Fig. 8a). The slope of modeled versus measured plant size at $100 \%$ irradiance, however, was not significantly different from 1.0 (Fig. 8b, Table 5).

The discrepancy between modeled and measured plant size could be explained by differences in irradiance measured by the scalar PAR sensor and the irradiance actually harvested by the kelp blades. The scalar irradiance sensor is designed to collect PAR from all directions. Light absorption by a planar blade, like that of Pleurophycus gardneri, exhibits a cosine response to the incident light field, and is spectrally biased against green light. According to the Cosine Law, downwelling irradiance experienced by the planar blade is proportional to the cosine of the angle between the leaf normal and the incident beam (Kirk 1994, Zimmerman 2003). Water motion alters the orientation of the blade surface relative to the submarine light field. Further, variations in stipe length, blade density, and blade overlap (self-shading), as well as spectral biases in the efficiency of PAR absorption, combine to make the photosynthetically utilized radiation considerably less than that measured by the broadband scalar irradiance sensor.

Model sensitivity to light collection efficiency was tested by reducing irradiance to $75,50,25,15$, and $10 \%$ of ambient. Model predictions of plant size through time using both 50 (Fig. 8) and 25\% (Fig. 8) of the measured irradiance resulted in the highest agreement with measured plant size. The intercepts of modeled versus measured plant size were statistically equivalent to 0 using 50 and $25 \%$ irradiance, and the seasonal pattern in modeled plant size was more consistent with measured plant size (Fig. 8, Table 5). Based on $\mathrm{r}^{2}$ values, $25 \%$ irradiance provided a marginally better fit of the model (Fig. 9), accounting for $76 \%$ of the variation, while $50 \%$ irradiance explained $73 \%$ of the variation. Secondary regression analysis determined that the regression of modeled versus measured plant size for both 50 and $25 \%$ irradiance produced slopes that were statistically identical to 1 (Table 5). The annual $P_{\text {NET }}$ was $5.14 \mathrm{~g} \mathrm{C}$ plant $^{-1}$ for $50 \%$ of measured irradiance and $0.16 \mathrm{~g} \mathrm{C} \mathrm{plant}^{-1}$ for $25 \%$ of measured irradiance. Values of $P_{\mathrm{NET}}$ for 15 and $10 \%$ irradiance were lower, and $\mathrm{r}^{2}$ values dropped to 0.74 at $15 \%$ and 0.70 at $10 \%$.

The 50 and $25 \%$ irradiance values (most accurate predictors of plant size) were used to evaluate the effect of blade retention on average daily whole-plant $P_{\mathrm{NET}}\left(\mathrm{g} \mathrm{C}\right.$ plant $^{-1}$ ) throughout the fall and winter. To simulate the effects of blade retention, the calculations were initialized with plant size from May 2000, but no
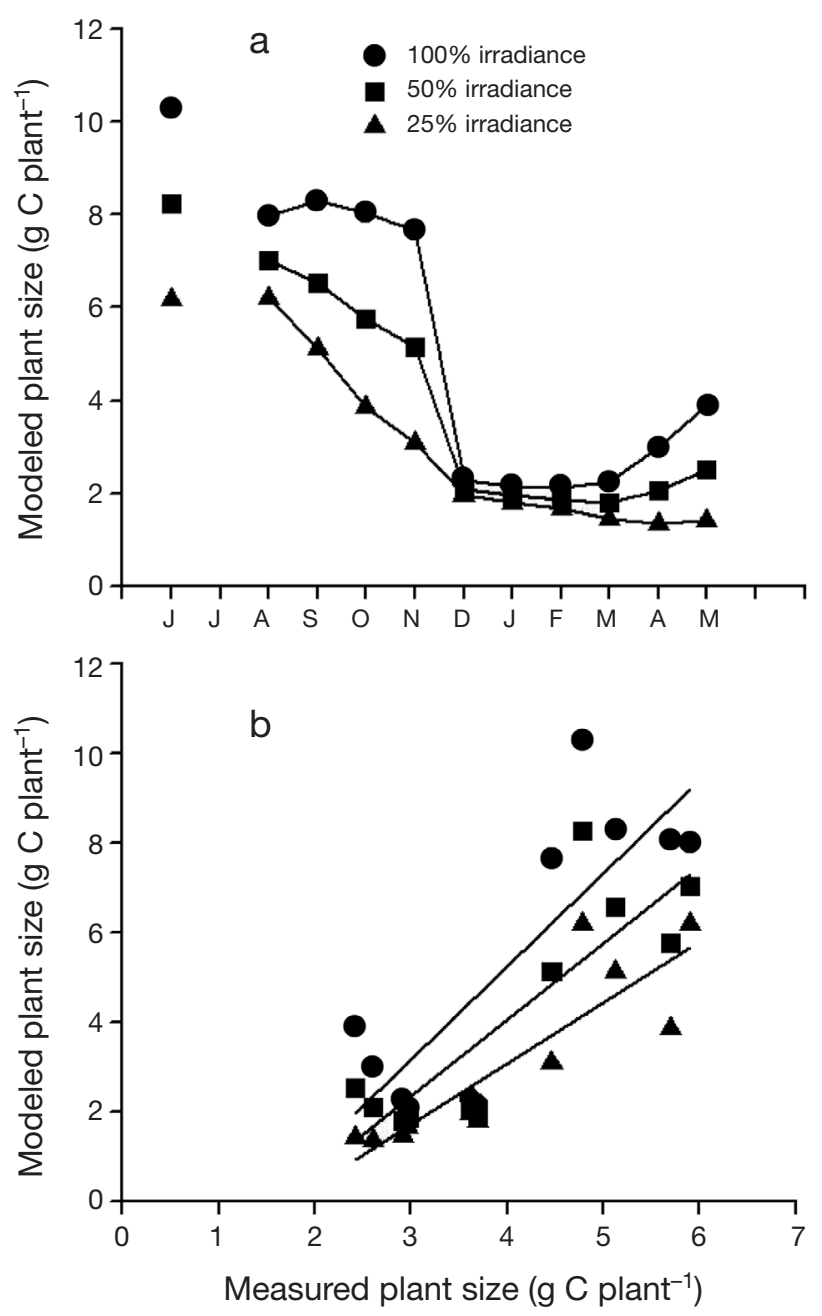

Fig. 8. Pleurophycus gardneri. (a) Modeled plant size at 100, 50, and $25 \%$ irradiance. (b) Measured plant size versus modeled plant size at 100,50 , and $25 \%$ irradiance

sloughing or abscission was allowed. Respiration and growth were the only possible fates for the photosynthetically fixed carbon driven by the irradiance time series. At $25 \%$ irradiance, hypothetical retention of the blade yielded higher mean $P_{\mathrm{NET}}$ in late summer and spring, and lower $P_{\mathrm{NET}}$ in winter, than the run allowing abscission (Fig. 10a). Without abscission, mean daily $P_{\mathrm{NET}}$ was positive in the spring and summer (March through August), but negative in the fall and winter (September through February). With abscission, mean daily $P_{\mathrm{NET}}$ was only positive in the early summer, and was negative from August to May. The blade retention scenario simulated using $50 \%$ of the measured irradiance yielded consistently positive values of $P_{\mathrm{NET}}$ that were significantly higher than the simulation allowing abscission for all months except May 2001 (Fig. 10b). Annual $P_{\mathrm{NET}}$ for $25 \%$ irradiance with no abscission was $1.22 \mathrm{~g} \mathrm{C} \mathrm{plant}^{-1}$, and annual $P_{\mathrm{NET}}$ for $50 \%$ with no 
Table 5. Pleurophycus gardneri. Regression analysis for modeled versus measured plant size for all irradiance correction factors and back-calculations

\begin{tabular}{|c|c|c|c|c|c|c|c|c|}
\hline $\begin{array}{c}\text { Irradiance correction } \\
\text { factor }(\%)\end{array}$ & $(\mathrm{df}, \mathrm{n})$ & $\mathrm{r}^{2}$ & \multicolumn{2}{|c|}{ Slope $( \pm \mathrm{SE})$} & $\begin{array}{l}\text { Slope regression } \\
\text { ANOVA } F\end{array}$ & Slope p & Intercept ( $(\mathrm{SE})$ & Intercept $\mathrm{p}$ \\
\hline 100 & $(1,11)$ & 0.67 & \multicolumn{2}{|c|}{$2.07( \pm 0.48)$} & 18.41 & 0.0020 & $-3.06( \pm 2.00)$ & 0.165 \\
\hline 75 & $(1,11)$ & 0.70 & \multicolumn{2}{|c|}{$1.91( \pm 0.42)$} & 20.75 & 0.0014 & $-2.93( \pm 1.76)$ & 0.131 \\
\hline 50 & $(1,11)$ & 0.73 & \multicolumn{2}{|c|}{$1.70( \pm 0.34)$} & 24.80 & 0.0008 & $-2.72( \pm 1.42)$ & 0.089 \\
\hline 25 & $(1,11)$ & 0.76 & \multicolumn{2}{|c|}{$1.36( \pm 0.25)$} & 29.23 & 0.0004 & $-2.36( \pm 1.05)$ & 0.052 \\
\hline 15 & $(1,11)$ & 0.74 & \multicolumn{2}{|c|}{$1.18( \pm 0.23)$} & 25.87 & 0.0007 & $-2.18( \pm 0.97)$ & 0.052 \\
\hline 10 & $(1,11)$ & 0.70 & \multicolumn{2}{|c|}{$1.08( \pm 0.24)$} & 20.68 & 0.0014 & $-2.08( \pm 0.99)$ & 0.066 \\
\hline Back-calculated & $(1,11)$ & 0.87 & \multicolumn{2}{|c|}{$0.917( \pm 0.12)$} & 61.75 & 0.000026 & $0.25( \pm 0.53)$ & 0.641 \\
\hline \multicolumn{9}{|c|}{ Summary of standard regression $H_{\mathrm{o}}$ : slope $=1$, intercept $=0$} \\
\hline $\begin{array}{c}\text { Irradiance correction } \\
\text { factor }(\%)\end{array}$ & $(\mathrm{df}, \mathrm{n})$ & $\begin{array}{l}\text { Slope } \\
( \pm \text { SE })\end{array}$ & $95 \% \mathrm{CI}$ & $\mathrm{p}$ & $\begin{array}{l}\text { Different } \\
\text { from } 1\end{array}$ & & & \\
\hline 100 & $(1,11)$ & 2.070 & 1.09 & $>0.05$ & No & & & \\
\hline 75 & $(1,11)$ & 1.910 & 0.95 & $>0.05$ & No & & & \\
\hline 50 & $(1,11)$ & 1.700 & 0.77 & $>0.05$ & No & & & \\
\hline 25 & $(1,11)$ & 1.360 & 0.57 & $>0.05$ & No & & & \\
\hline 15 & $(1,11)$ & 1.180 & 0.52 & $>0.05$ & No & & & \\
\hline 10 & $(1,11)$ & 1.080 & 0.54 & $>0.05$ & No & & & \\
\hline Back-calculated & $(1,11)$ & 0.917 & 0.27 & $>0.05$ & No & & & \\
\hline
\end{tabular}

abscission was $11.74 \mathrm{~g} \mathrm{C}$ plant $^{-1}$. Annual $P_{\mathrm{NET}}$ at $25 \%$ irradiance with abscission of the blade was $-0.159 \mathrm{~g} \mathrm{C}$ plant $^{-1}$, and at $50 \%$ irradiance with abscission, $5.14 \mathrm{~g}$ C plant ${ }^{-1}$.

Stipe and holdfast survival for the bladeless period was calculated by converting the carbon content of the soluble carbohydrate reserves into respiratory equivalents, assuming no photosynthetic production in the perennial tissues. The carbohydrate content of the stipe and holdfast in November would support the winter-time respiration rate of the stipe and holdfast for 2.8 mo. Photosynthesis production by the stipe and holdfast could only support 20 to $30 \%$ of the respiratory load over the winter.

\section{DISCUSSION}

Pleurophycus gardneri is unique among the Laminariales in having a life history characterized by annually deciduous blades. Whether abscission is regulated by a response to temperature (Germann 1986) or photoperiod (Lüning \& Kadel 1993), the loss of blade tissue was thought to provide an adaptation for persistence during the winter period of low light availability. The carbon budgets calculated here, however, demonstrate that abscission does not provide an effective metabolic strategy for this deep-water population, because blade retention permitted higher rates of daily $P_{\mathrm{NET}}$ throughout the year, including the winter. Thus, abscission may be related to other factors
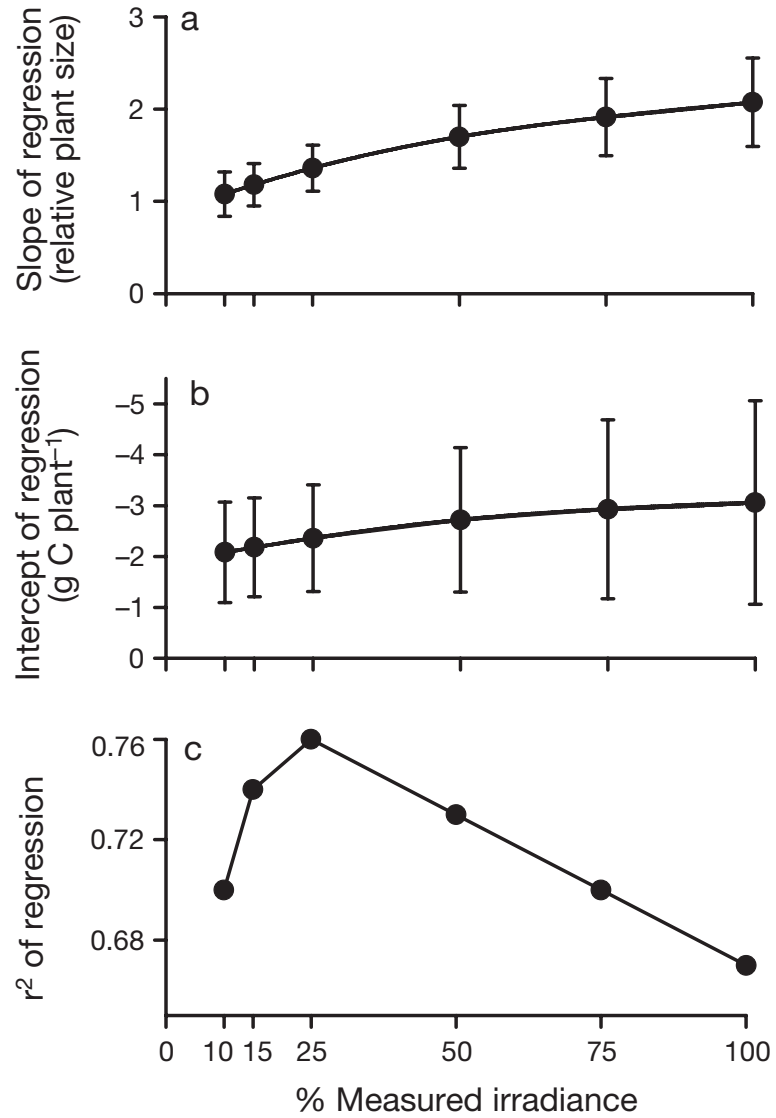

Fig. 9. Pleurophycus gardneri. Regression parameters for modeled versus measured plant size plotted as a function of the percentage of measured irradiance: (a) regression slopes $( \pm \mathrm{SE}),(\mathrm{b})$ regression intercepts $( \pm \mathrm{SE})$, and $(\mathrm{c}) \mathrm{r}^{2}$ of regression 


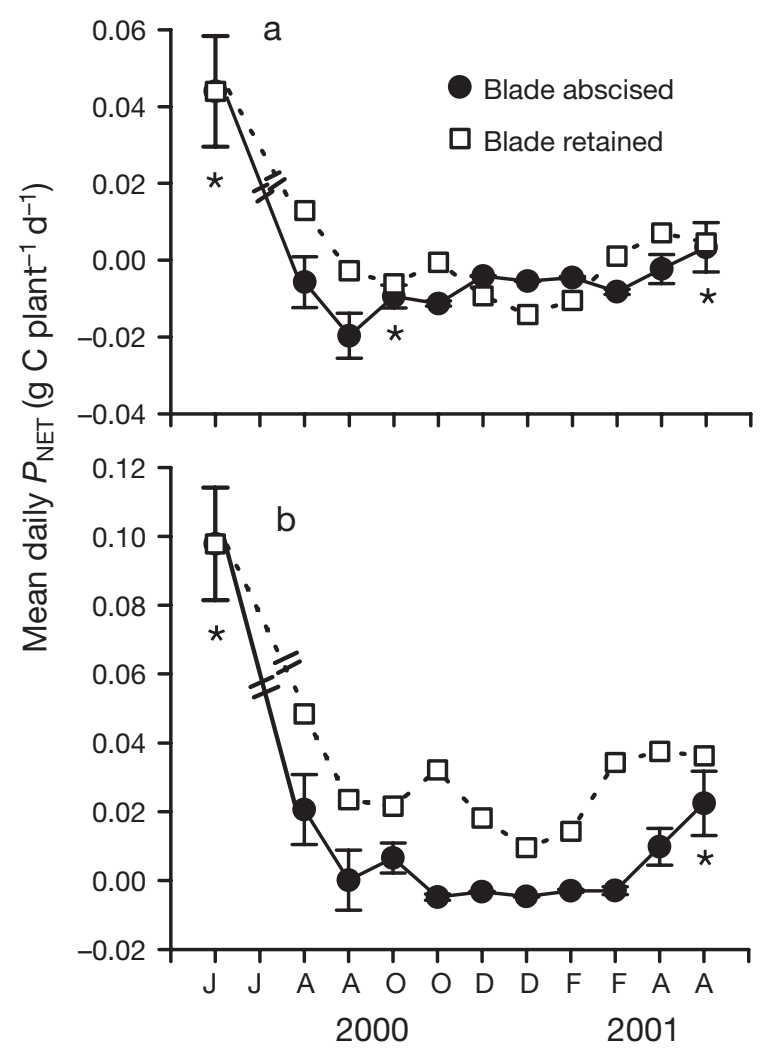

Fig. 10. Pleurophycus gardneri. Effect of abscission on daily, whole-plant, net photosynthesis: (a) average daily $P_{\text {NET }}$ assuming $25 \%$ of measured irradiance and (b) average daily $P_{\mathrm{NET}}$ assuming $50 \%$ of measured irradiance. *: months when 'blade abscised' was not significantly different from 'blade retained'. Break indicates missing data point in July 2000

including spore dispersal (Addicott 1982) and/or increased survival of intense winter storms by reducing the drag imposed by large swells on the bladeless stipes (Denny 1988).

The carbon budget calculations captured the seasonal pattern of plant growth, but overpredicted plant size by a factor of 2 when driven by the measured scalar irradiances. This degree of overprediction is consistent with other field-laboratory comparisons (Fourqurean \& Zieman 1991, Herzka \& Dunton 1997), and should be expected when scalar field irradiances used to drive models based on laboratory $P$ versus $E$ curves are not corrected for the geometric orientation of photosynthetic blades, which act as cosine irradiance collectors (Zimmerman 2003). The laboratory measurements of photosynthesis performed in this study used blade surfaces oriented normal to the light, which maximized interception of radiant flux. Blades in the field, however, are rarely oriented normal to the incident flux. The 50 and $25 \%$ irradiance values, which generated the most reliable predictions of plant size, corresponded to mean blade orientations of 60 and $75^{\circ}$ from the horizontal. The resulting quasi-vertical orientation is fairly typical of these blades, particularly when they are moving in response to surge. Although canopy density effects were not simulated here, fronds can overlap and shade each other, especially in summer when total blade area is high and surge is low.

In addition to blade orientation, light quality may have a significant effect on in situ photosynthesis of this deep-water kelp. Morel (1978) demonstrated that the radiation actually utilized for photosynthesis (PUR) by deep-dwelling phytoplankton in waters dominated by poorly absorbed green/yellow light could be as low as $1 / 3$ of the measured PAR, depending on water type. Considering the differences in light absorbed by the spherical irradiance sensor versus the flat blades (cosine collectors) and the potential difference in PAR versus PUR, it appears reasonable that only 25 to $50 \%$ of measured scalar irradiance was actually used for photosynthesis. Further refinement of this carbon budget model to include the optical properties of the blades themselves, the effects of water motion on blade angle and light absorption, PAR versus PUR, and density-dependent-shading effects would permit determination of the light-limited depth distribution of this species.

The irradiances ranging from 0 to $1 \mathrm{~mol}$ quanta $\mathrm{m}^{-2}$ $\mathrm{d}^{-1}$ measured here during winter were similar to those of the Arctic under seasonal ice cover in winter (Chapman \& Lindley 1980, Dunton 1990). However, the Arctic benthos receives higher irradiances during the summer (up to $8 \mathrm{~mol}$ quanta $\mathrm{m}^{-2} \mathrm{~d}^{-1}$ ) and day-length is twice as long ( $P_{\mathrm{MAX}}$ would be integrated over $24 \mathrm{~h}$ rather than $12 \mathrm{~h}$ ). During nutrient limitation in Arctic summer, some kelps cease growth and divert all production to carbohydrate storage (Chapman \& Lindley 1980, Dunton 1990). These stored carbohydrates are used to fuel $90 \%$ of annual plant growth during the winter period of darkness when nutrients are abundant. Laminariales can accumulate up to 15 to $20 \%$ DW in carbohydrates (German 1986, Watanabe et al. 1992). The deep-water population of Pleurophycus gardneri examined here, however, only accumulated 5 to $9 \%$ DW as carbohydrates, with the stipe the main reservoir and the blade the main source. Unlike the Arctic, summer irradiances at our East Pinnacles study site near Monterey Bay were highly variable due to frequent dense coastal stratus and periodic, phytoplankton blooms driven by the temporal dynamics of coastal upwelling (Olivieri \& Chavez 2000). Thus, the combination of high ambient nutrient concentrations and low light availability probably limits the summertime accumulation of large internal carbon reserves by $P$. gardneri in comparison to other kelps, including intertidal populations of this species growing at higher latitudes. 
Some of the carbohydrates accumulated in the blade during summer may have been translocated to the stipe and holdfast prior to blade abscission, a process which has been documented in Pleurophycus gardneri (Schmitz 1982). Carbon content of the stipe decreased during spring, perhaps due to remobilization and utilization of carbohydrates for growth of the blade. Germann's (1989) suggestion, that translocation from the blade to the stipe was not possible due to the lack of blade growth in complete darkness, assumed that blade growth only required the presence of carbohydrate reserves. It did not consider the presence of a growth-initiating trigger, which may be controlled by photoperiod (Lüning \& Kadel 1993). Reserves accumulated prior to abscission were sufficient for winter respiratory requirements, allowing for 2 mo of respiration during winter and a buffer of about another month during blade initiation in spring. In addition, stipe and holdfast photosynthesis could only account for 20 to $30 \%$ of the respiratory demand over the winter, which was augmented by slightly reduced respiration rates and a higher fucoxanthin to chlorophyll a ratio during winter.

Although this study revealed no evidence of major seasonal photoacclimation in Pleurophycus gardneri, differences in the magnitude of physiological parameters ( $\alpha$ and chl) between the deep population studied here and the intertidal plants measured by Germann (1989) were evident. These deep-water plants exhibited higher light utilization efficiencies than intertidal plants on a biomass basis, but lower efficiencies on a chlorophyll-specific basis. This pattern represents a classic photoacclimation response common to shadeadapted algae. The $P / R$ ratio was slightly higher in this deep-water population than in the intertidal one studied by Germann (1989); however, it was not higher than in other kelps such as Macrocystis pyrifera (Zimmerman \& Kremer 1986, Table 4).

Size and morphology of these deep-water plants were also different from those studied by Germann (1986). Average stipe lengths of those deep adult plants chosen for this study were generally twice as long (40 to $50 \mathrm{~cm}$ ) as the average stipe length of intertidal plants $(20 \mathrm{~cm})$ studied by Germann (1986), but blade area was similar to intertidal plants. Stipes of deep plants exhibited a 'step-like' pattern of growth (referred to as growth constrictions). The top of the stipe was flat and broad near the blade junction, then narrowed and became elliptical with each constriction (with slight turning and rounding between constrictions), and was round toward the holdfast. Although stipe growth was not quantitatively measured during the bladeless period, cell expansion or growth was observed just below the meristem, as indicated by several centimeters of new, lightly pigmented tissue.
Growth rings in the basal portion of the stipe of deepwater Pleurophycus gardneri were unexpected because they are absent in intertidal plants (Germann 1986). Validation of growth ring chronology allowed assessment of maximum observed age of $5 \mathrm{yr}$ in this deep-water population (Dominik 2004). These plants abscised 1 mo later than intertidal plants and remained bladeless for $2 \mathrm{mo}$, instead of $2 \mathrm{wk}$ like intertidal plants (Germann 1986). Because intertidal plants contain $\sim 10$ times more sugar than the deep plants, they have enough reserves to grow despite the short day-lengths in winter, so that when spring arrives they already have a large blade for quick growth and re-accumulation of sugar for the next winter. Deep plants have so little sugar that they must survive on reserves until spring, when ample light is available for growth.

Some of these morphological and physiological differences may indicate adaptations to surviving in a deep-water environment. Higher water motion in the intertidal may cause plants with longer stipes to be removed, effectively decreasing the average stipe length compared to deep plants. Longer stipes of the deep-water plants may help prevent self-shading and reduce light competition by placing the blades higher in the water column, where they are exposed to higher rates of water motion. Production of additional sori just prior to abscission may facilitate dispersal as the negatively buoyant blade drifts away.

The deep-water population of Pleurophycus gardneri did not accumulate large carbohydrate reserves compared to other kelps, and the annual carbon budget appears to be tightly balanced. Despite the potential benefit demonstrated by the model of retaining the blade, classic photoacclimation and seasonally depressed respiration in the perennial parts apparently allow this deciduous kelp to persist in deeper water. Without the reserves located in the perennial stipe and holdfast the plant should die before blade initiation in spring. The photosynthetic efficiency of deep-water plants was twice that of intertidal plants, which have very low compensation depths (Germann 1986). This study also demonstrated that models, which incorporate photosynthetic production, should account for canopy geometry and orientation relative to the submarine light field and possibly the quality of in addition to the quantity of in situ irradiance.

Acknowledgements. Many thanks to M. S. Foster for initially proposing this study, for extensive advice and guidance on experimental design, and for data analysis throughout the course of this study. J. Schuytema produced the scientific illustration. J. Heine, L. Bradford, A. Bullard, and J. Felton provided logistical support and field assistance. Funding was provided by the Packard Foundation, the PADI AWARE 
Foundation, the Earl and Ethyl Meyers Oceanographic Trust, and the NOAA National Undersea Research Program (NURP), Monterey Bay Initiative.

\section{LITERATURE CITED}

Abbott IA, Hollenberg GJ (1976) Marine algae of California. Stanford University Press, Stanford, CA

Addicott FT (1982) Abscission. University of California Press, Berkeley, CA

Chapman ARO, Craigie JS (1977) Seasonal growth in Laminaria longicruris: relations with dissolved inorganic nutrients and internal reserves of nitrogen. Mar Biol 40: 197-205

Chapman ARO, Craige JS (1978) Seasonal growth in Laminaria longicruris: relations with reserve carbohydrate storage and production. Mar Biol 46:209-213

Chapman ARO, Lindley JE (1980) Seasonal growth of Laminaria solidungula in the Canadian high Arctic in relation to irradiance and dissolved nutrient concentrations. Mar Biol 57:1-5

Chapman ARO, Markham JW, Lüning K (1978) Effects of nitrate concentrations on the growth and physiology of Laminaria saccharina (Phaeophyta) in culture. J Phycol 14: 195-198

Dean TA (1985) The temporal and spatial distribution of underwater quantum irradiance in a southern California kelp forest. Estuar Coast Shelf Sci 21:835-844

Denny MW (1988) Biology and the mechanics of the wave swept environment. Princeton University Press, Princeton, NJ

Dominik CM (2004) Dynamics of carbon allocation in a deep water population of the deciduous kelp, Pleurophycus gardneri (Laminariales). MS thesis, California State University Moss Landing Marine Laboratories, Moss Landing, CA

Dunton KH (1985) Growth of dark-exposed Laminaria saccharina (L.) Lamour. and Laminaria solidungula J. Ag. (Laminariales: Phaeophyta) in the Alaskan Beaufort Sea. J Exp Mar Biol Ecol 94:181-189

Dunton KH (1990) Growth and production in Laminaria solidungula: relation to continuous underwater light levels in the Alaskan high Arctic. Mar Biol 106:297-304

Dunton KH, Jodwalis CM (1988) Photosynthesis performance of Laminaria solidungula measured in situ in the Alaska high Arctic. Mar Biol 98:277-285

Dunton KH, Schell DM (1986) Seasonal carbon budget and growth of Laminaria solidungula in the Alaskan high Arctic. Mar Ecol Prog Ser 31:57-66

Edwards MS (1998) Effects of long-term kelp canopy exclusion on the abundance of the annual alga Desmerestia ligulata (Light F). J Exp Mar Biol Ecol 228:309-326

Fourqurean JW, Zieman JC (1991) Photosynthesis, respiration and whole plant carbon budget of the seagrass Thalassia testudinum. Mar Ecol Prog Ser 69:161-170

Gagne JA, Mann KH, Chapman ARO (1982) Seasonal patterns of growth and storage in Laminaria longicruris in relation to differing patterns of available nitrogen in water. Mar Biol 69:91-101

Germann I (1986) Growth phenology of Pleurophycus gardneri (Phaeophyceae, Laminariales), a deciduous kelp of the northeast Pacific. Can J Bot 64:2538-2547

Germann I (1989) Aspects of carbon metabolism in relation to autumnal blade abscission in the kelp Pleurophycus gardneri (Phaeophyceae, Laminariales). Mar Ecol Prog Ser 54: 179-183
Germann I, Druehl LD, Hoeger U (1987) Seasonal variation of total soluble tissue nitrogen in Pleurophycus gardneri (Phaeophyceae, Laminariales) in relation to environmental nitrate. Mar Biol 96:413-423

Herzka S, Dunton K (1997) Seasonal photosynthetic patterns in the seagrass Thalassia testudinum in the western Gulf of Mexico. Mar Ecol Prog Ser 152:103-117

Kirk JTO (1994) Light and photosynthesis in aquatic ecosystems, 2nd edn. Cambridge University Press, Cambridge

Lambert M, Neish AC (1950) Rapid method for estimation of glycerol in fermentation solutions. Can J Res 28B:83-89

Lüning K (1979) Growth strategies of three Laminaria species (Phaeophyceae) inhabiting different depth zones in the sublittoral region of Helgoland (North Sea). Mar Ecol Prog Ser 1:195-207

Lüning K, Kadel P (1993) Daylength range for circannual rhythmicity in Pterogophora californica (Alariaceae, Phaeophyta) and synchronization of seasonal growth by daylength cycles in several other brown algae. Phycologia 32:379-387

Lüning K, Schmitz K, Willenbrink J (1973) $\mathrm{CO}_{2}$ fixation and translocation in benthic marine algae. III. Rates and ecological significance of translocation in Lamiaria hyperborea and L. saccharina. Mar Biol 23:275-281

Mann KH (1973) Seaweeds: their productivity and strategy for growth. Science 182:975-981

Markham JW (1972) Distribution and taxonomy of Laminaria sinclairii and L. longipes (Phaeophyceae, Laminariales). Phycologia 11:147-157

Morel A (1978) Available, usable, and stored radiant energy in relation to marine photosynthesis. Deep-Sea Res 25:673-688

Olivieri RA, Chavez FP (2000) A model of plankton dynamics for the coastal upwelling system of Monterey Bay, California. Deep-Sea Res II 47:1077-1106

Parke MW (1948) Studies of the British Laminariaceae. I. Growth in Laminaria saccharina (L.) Lamour. J Mar Biol Assoc UK 27:651-709

Ramus J (1983) A physiological test of the theory of complementary chromatic adaptation. II. Brown, green and red seaweeds. J Phycol 19:173-178

Reed DC, Foster MS (1984) The effect of canopy shading on algal recruitment and growth in a kelp forest. Ecology 65: 937-948

Schiel DR, Foster MS (1986) The structure of subtidal algal stands in temperate waters. Oceanogr Mar Biol Annu Rev 24:265-307

Schmitz K (1982) Translocation of organic compounds in Laminariales. In: Synthetic and degradative processes in marine macrophytes. Walter de Gruyter, Berlin, p 167-180

Sears JR, Wilce RT (1975) Sublittoral, benthic marine algae of southern Cape Cod and adjacent islands: seasonal periodicity, associations, diversity, and floristic composition. Ecol Monogr 45:337-365

Seely GP, Duncan MJ, Vidaver WE (1972) Preparative and analytical extraction of pigments from brown algae with dimethyl sulfoxide. Mar Biol 54:179-188

Sokal RR, Rohlf FJ (1969) Biometry: the principles and practices of statistics in biological research, 2nd edn. WH Freeman, San Francisco, CA

Spalding H, Foster MS, Heine JH (2003) Composition, distribution, and abundance of deep-water $(>30 \mathrm{~m})$ macroalgae in central California. J Phycol 39:273-284

VanBlaricom GR, Reed DC, Harrold C, Bodkin JL (1986) A sublittoral population of Pleurophycus gardneri (Setchell and Saunders, 1900) (Phaeophyceae: Laminariaceae) in central California. Bull South Calif Acad Sci 85:120-122

Watanabe JM, Phillips RE, Allen NH, Anderson WA (1992) Physiological response of the stipitate understory kelp, 
Pterygophora californica Ruprecht, to shading by the giant kelp, Macrocystis pyrifera C. Agardh. J Exp Mar Biol Ecol 159:237-252

Webb WL, Newton M, Starr D (1974) Carbon dioxide exchange of Alnus rubra: a mathematical model. Oecologia 17:281-291

Yemn EW, Willis AL (1954) The estimation of carbohydrates in plant extracts by anthrone. Biochem J 57:508-514

Zimmerman RC (2003) A biooptical model of irradiance distribution and photosynthesis in seagrass canopies. Limnol Oceanogr 48:568-585

Editorial responsibility: Otto Kinne (Editor-in-Chief), Oldendorf/Luhe, Germany
Zimmerman RC, Kremer NJ (1986) In situ growth and chemical composition of the giant kelp, Macrocystis pyrifera: response to temporal changes in ambient nutrient availability. Mar Ecol Prog Ser 27:277-285

Zimmerman RC, Beeler SooHoo JB, Kremer JN, Argenio DZD (1987) Evaluation of variance approximation techniques for non-linear photosynthesis-irradiance models. Mar Biol 95:209-215

Zimmerman RC, Smith RD, Alberte RS (1989) Thermal acclimation and whole-plant carbon balance in Zostera marina L. (eelgrass). J Exp Mar Biol Ecol 130:93-109

Submitted: March 8, 2005; Accepted: September 19, 2005 Proofs received from author(s): February 10, 2006 